\title{
TRIBUTE TO CHIEF JUSTICE HARRY L. CARRICO
}

\section{John G. Douglass *}

My first encounter with Chief Justice Harry Carrico came just a few months after I was admitted to the Virginia Bar. It didn't go quite as I had planned. As a brand new lawyer I somehow had landed an opportunity to argue a case in the Supreme Court of Virginia. After a sleepless night of pre-game jitters, I sat a bit bleary eyed at counsel table and counted my heartbeats. The Clerk called out his "oyez" and an imposing array of white-haired Justices appeared from behind a crimson curtain to take their seats on a bench so impossibly high that it seemed like only the tops of their heads were visible. A voice from on high called my name. I stood. And then it happened. As I scooped a collection of notes and briefs into my arms, my oversized notebook slipped, a crystal water goblet fell from counsel table, glass clanked, ice flew and water plunged onto the Court's very plush, very red and theretofore very dry carpet. I froze, only half a step into my fledgling career as a courtroom lawyer, already marked as a bumbler. I waited for the voice of reproach from the bench, expecting at least a mildly annoyed "hrrumph." Instead, I heard the gracious words: "Don't worry, counsel. I've done that a few times myself. Please proceed with your argument." I looked up to see the very genuine smile and twinkling eyes of Chief Justice Harry Carrico.

By the time of our courtroom encounter in 1981, Justice Carrico had seen twenty years of nervous lawyers at oral arguments in the court where he was to serve longer than any Justice. He had just become Chief. It would be another twenty-two years, just after he "retired" to senior status in 2003, before I would have the privilege to know him as a friend and colleague on our law school faculty. Only then did I learn that the self-effacing grace

* Professor of Law, University of Richmond School of Law. J.D., 1980, Harvard Law School; B.A., 1977, Dartmouth College. 
he showed to that fledgling lawyer in 1981 was his defining characteristic.

Justice Carrico was eighty-six when we first worked together at the law school, but I never knew him as "old." When he visited my house for law school events in my years as Dean, he insisted on walking up the long gravel driveway rather than asking someone decades younger to park his car. Whenever he arrived at the law school he carried a stack of red and blue briefs to read between student appointments. He continued to serve the court as Senior Justice until just a few months before his death, still writing opinions and sitting on writ panels. And I have seen photographic evidence of his exploits on roller blades well into his eighties.

When Dean John Pagan presented Justice Carrico's portrait in 2003, he remarked that the retiring Chief Justice had "adopted" our law school. Justice Carrico's typically humble response was that the law school had adopted him. Both were true. The University awarded Justice Carrico an honorary Doctor of Laws in 1973 while his daughter, Lucretia, was an undergraduate. She later earned her J.D. from the law school and now continues the family tradition of service on the Virginia bench. In 1987 the law school gave Chief Justice Carrico its highest honor, the William Green Award for Professional Excellence, a fitting tribute to a man who's commitment to professionalism, civility and excellence is legendary across our Commonwealth. In 2003 he helped organize a major conference on judicial independence, a topic close to his heart, and participated on a panel with William Rehnquist, Chief Justice of the United States Supreme Court. A few years later Justice Carrico joined with our former Dean Rodney Smolla to produce a widely circulated video on professionalism, a fitting encore to his earlier brainchild, the Course on Professionalism for all newly admitted members of the Virginia Bar, the first course of its kind in the nation. In 2008 the law school named the Harry L. Carrico Center for Pro Bono Services to mark his career-long commitment to fostering pro bono service throughout the Virginia Bar.

The mutual "adoption" included a good deal more than public appearances, degrees and honors. What mattered most to Justice Carrico were the students he met here. After he joined our faculty in 2004 as Visiting Professor of Law and Civic Engagement, he taught the John Marshall seminar and sat on the Marshall Scho- 
larship selection committee. With his typically personal touch, he called every scholarship recipient and welcomed them to the law school. Each year he judged the final round of the moot court competition that bears his name. Commenting on the performance of student advocates, he said, "I hope they are as well prepared in real life as they are for moot court. When I was in law school, I doubt that I could have stood up there before three judges who look as stern as we must look. I think the floor would have opened up and swallowed me."

Most remarkable to me, Justice Carrico visited the law school each week to hold "office hours" for students. There was no agenda, no curriculum other than his lifetime of experience. He devoted countless hours to those personal conversations with hundreds of students, talking about whatever mattered to them. Justice Carrico touched those lives in ways the students probably did not anticipate. No doubt they sought the wisdom of a judicial icon. No doubt he delivered. But in the process they also discovered the open-hearted humanity of a quiet-natured gentleman who, despite being three times their ages, related to them with a graceful and humble nature that few had imagined.

I was touched by that grace in my first months as a lawyer and, again, decades later. At the memorial service in the University Chapel I joined with hundreds of others who shared similar memories of this "gentle giant" in the law who wore his judicial robe with equal measures of dignity and humility. One speaker put it most aptly, quoting the prophet, Micah: "What does the Lord require of you but to do justice, to love mercy, and to walk humbly with your God?" So lived Chief Justice Harry L. Carrico. 